\title{
PERSEPSI KONSUMEN PADA ENDORSER SELEBRITI PRODUK SHAMPO MEREK PANTENE
}

\author{
Marsudi ${ }^{1}$ \\ Program Studi Manajemen, Universitas Muhammadiyah Malang ${ }^{1}$
}

\begin{abstract}
Abstrak
Tujuan penelitian ini adalah untuk mengetahui persepsi konsumen terhadap endorser selebriti produk shampo merek Pantene sekaligus variabel yang paling dominan berpengaruh terhadap persepsi konsumen diantara variabel visibility, credibility, attraction dan power selebriti yang digunakan sebagai konstruk dari variabel endorser. Dari hasil penelitian yang akan dilakukan diperoleh bahwa persepsi konsumen tinggi diperkirakan untuk penilaian pada attraction sebagai endorser produk shampo merek Pantene. Hal ini dapat dilihat dari nilai rata-rata skor indikator tersebut diperkirakan masuk pada kriteria tinggi. Indikator yang dimiliki selebritis diharapkan mempunyai daya tarik fisik/penampilan yang menarik, dan berkualitas baik dari segi kepribadian maupun kecantikan yang dimiliki endorser.
\end{abstract}

Kata Kunci : Persepsi konsumen, endorser selebriti

\section{PENDAHULUAN}

Salah satu fungsi perusahaan yang berkembang dan dapat dipakai sebagai ujung tombak keberhasilan pencapaian laba adalah fungsi pemasaran. Dengan demikian, untuk memanfaatkan dan merebut peluang pasar yang ada, maka setiap perusahaan, harus mampu mendayagunakan keseluruhan aktifitas usaha pemasaran secara optimal dengan menerapkan fungsi-fungsi pemasaran yang lebih efektif.

Ada banyak cara yang digunakan oleh perusahaan dalam meraih pangsa pasar, apabila perusahaan tergolong besar, dapat menggunakan media sebagai jembatan dengan masyarakat sebagai konsumen. Media yang digunakan oleh perusahaan bermacam-macam, hal ini dapat ditentukan dari cakupan masyarakat yang akan dituju oleh perusahaan bermacam-macam, hal ini dapat ditentukan dari cakupan masyarakat yang akan dituju oleh prusahaan tersebut dan seberapa efektif media tersebut menjadi jembatan bagi perusahaan dengan masyarakat. Kata media menjadi tidak asing lagi bagi sebuah perusahaan yang besar dan bersaing untuk menjadi yang teratas. Dalam media, perusahaan dapat mengeluarkan inspirasi yang ingin disampaikan kepada masyarakat luas sebagai konsumen maupun masyarakat sebagai pengamat.

Keberagaman media saat ini menjadikan perusahaan semakin mudah untuk menentukan arah dan tujuan dalam penggunaan media yang dipilih. Aspek komunikasi massa menjadi hal utama dalam hubungan dengan media terkait dari beberapa media yang ada, televisi merupakan salah satu media yang mencakup khalayak luas. Sedangkan tujuan akhir dari penyampaian pesan media televisi adalah memiliki kekuatan yang sangat tinggi untuk mempengaruhi mental, pola pikir, dan tindak individu (Baksin, 2006: 16)

Salah satu usaha yang dilakukan oleh perusahaan adalah melalui iklan.iklan sebagai salah satu bentuk komunikasi massa yang berfungsi untuk menginformasikan pesan kepada khlayak dan mempengaruhinya untuk melakukan tindakan tertentu memerlukan penanganan khusus dalam penciptaanya.

Upaya mencapai tujuan yang diinginkan, perusahaan atau pemasang iklan harus memperhatikan bebrapa aspek salah satu yang amat penting adalah komumikator. Kebanyakan orang saat ini cenderung untuk melihat siapa yang mengkomunikasikan pesan ketimbang apa yang dikomunikasikan. (Ardianto dan Komala, 2004). Untuk itu banyak perusahaan atau pemasang iklan berusaha untuk mencari komunikasi yang tepat untuk menyampaikan informasi tentang produknya.

Selebriti adalah tokoh pemeran yang dikenal masyarakat luas karena prestasinnya di bidang

\footnotetext{
1 marsudiudik@yahoo.com
} 
tertentu. Dalam pemasaran, mereka kerap dijadikan bintang iklan yang berperan sebagai endorser suatu produk, mereka popular atau dikenal masyarakat luas karena memiliki kelebihan seperti kecantikan, aktor film, pelawak, prestasi olahraga dan daya tarik lainya, sehinggan mereka seringkali merupakan pemikat yang ampuh bagi konsumen. Selebriti terkenal menjadi pertimbangan yang amat besar untuk menjadi komunikator dalam sebuah iklan, yang biasa disebut celebrity endorser. Selebriti yang sedang naik daun atau popular diyakini dapat mempengaruhi seseorang untuk mengambil tindakan tertentu sesuai dengan tujuan awal.

\section{Tujuan Penelitian}

1. Untuk mengetahui persepsi konsumen pada endorser selebriti produk shampo merek Pantene

2. Untuk mengetahui variabel yang dipersepsikan konsumen tertinggi diantara variabel visibility, credibility, attraction dan power yang digunakan sebagai endorser.

\section{METODE PENELITIAN}

Populasi dan Sampel

Malhotra (2004) menyatakan bahwa populasi adalah gabungan seluruh elemen yang memiliki serangkaian karakteristik serupa yang mencakup semesta untuk kepentingan masalah riset pemasaran. Menurut Santoso dan Tjiptono (2001) populasi merujuk pada sekelompok orang atau objek yang memiliki kesamaan dalam satu atau beberapa hal yang membentuk masalah pokok dalam suatu riset khusus. Populasi yang diteliti harus didefinisikan dengan jelas sebelum penelitian dilakukan. Populasi yang digunakan dalam penelitian konsumen pengguna shampo merek Pantene di kota Malang.

Sampel adalah bagian dari jumlah dan karakteristik yang dimiliki oleh populasi tersebut (Sugiyono, 2002).Jumlah populasi dalam penelitian ini tidak diketahui karena begitu banyak.

Teknik pengambilan sampel yang digunakan dalam penelitian ini adalah non probability sampling (purposive sampling). Teknik non probabilitas sampling adalah teknik pengambilan sampel yang tidak memberikan peluang / kesempatan yang sama bagi setiap unsur atau anggota populasi untuk dipilih menjadi sampel (Zikmund,2004).

\section{Metode Pengumpulan Data}

Dalam penelitian ini, untuk mengumpulkan data baik primer yang diperlukan untuk menganalisa sekaligus untuk penyusunan laporan penelitian, akan digunakan metode pengumpulan data dengan kuesioner. Menyebarkan daftar pertanyaan kepada responden atau sampel yang telah ditentukan.Daftar pertanyaan ini digunakan untuk mengungkap data atau keadaan yang lebih actual (data primer) yang tidak dapat ditunjukkan oleh data sekunder.

\section{Metode Analisis Data}

Rentang Skala digunakan untuk mendeskripsikan persepsi konsumen terhadap endorser produk shampo merek Pantene. Untuk menentukan rentang skala menggunakan rumus (Umar,2004:164) :

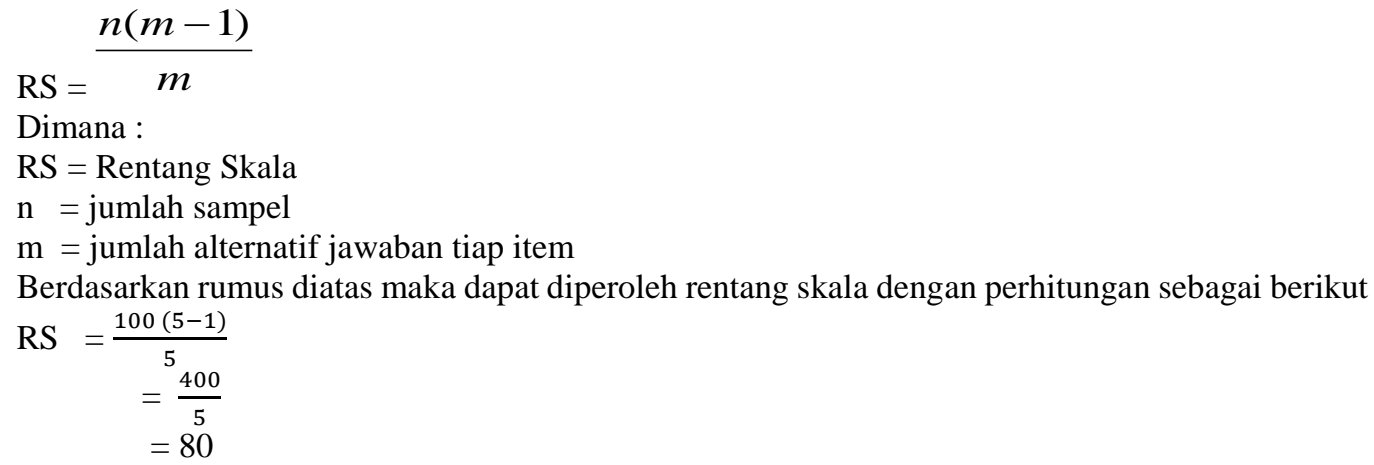

Berdasarkan perhitungan diatas maka diperoleh rentang skala sebagai berikut 
Tabel 1. Rentang Skala

\begin{tabular}{cc}
\hline Rentang Skala & $\begin{array}{c}\text { Persepsi } \\
\text { Konsumen }\end{array}$ \\
\hline $100-180$ & Sangat rendah \\
$181-260$ & Rendah \\
$261-340$ & Normal \\
$341-420$ & Tinggi \\
$421-500$ & Sangat Tinggi \\
\hline
\end{tabular}

\section{HASIL DAN PEMBAHASAN}

Hasil Analisis Rentang Skala

Analisis rentang skala digunakan untuk mengetahui persepsi konsumen terhadap endorser produk shampo merek Pantene. Untuk lebih jelasnya dapat dijelaskan sebagai berikut:

Tabel 2. Variabel Visibility

\begin{tabular}{|c|c|c|c|c|c|c|c|c|}
\hline \multirow[t]{2}{*}{ item } & \multirow[t]{2}{*}{ Keterangan } & \multicolumn{3}{|c|}{$\begin{array}{l}\text { Jawaban } \\
\text { responden }\end{array}$} & \multicolumn{2}{|c|}{ indikator } & \multirow{2}{*}{$\begin{array}{l}\text { Skor } \\
\text { total }\end{array}$} & \multirow[t]{2}{*}{ Kriteria } \\
\hline & & 1 & 2 & 3 & 4 & 5 & & \\
\hline $\mathrm{X} 1.1$ & $\begin{array}{l}\text { Endorser sangat } \\
\text { populer dalam iklan } \\
\text { produk shampo } \\
\text { merek Pantene }\end{array}$ & 1 & 10 & 4 & 64 & $\begin{array}{l}2 \\
1\end{array}$ & 394 & Tinggi \\
\hline $\mathrm{X} 1.2$ & $\begin{array}{l}\text { Endorser memiliki } \\
\text { rambut yang bagus } \\
\text { dibandingkan } \\
\text { dengan bintang iklan } \\
\text { shampo lain }\end{array}$ & 1 & 1 & 8 & 65 & $\begin{array}{l}2 \\
5\end{array}$ & 412 & Tinggi \\
\hline $\mathrm{X} 1.3$ & $\begin{array}{l}\text { Endorser memiliki } \\
\text { gaya rambut yang } \\
\text { sesuai dengan } \\
\text { produk yang } \\
\text { diiklankan }\end{array}$ & 1 & 9 & 4 & 63 & $\begin{array}{l}2 \\
3\end{array}$ & 398 & Tinggi \\
\hline X1.4 & $\begin{array}{l}\text { Konsumen shampo } \\
\text { merek Pantene } \\
\text { memiliki tingkat } \\
\text { kekaguman yang } \\
\text { tinggi terhadap } \\
\text { endorser }\end{array}$ & 1 & 9 & 3 & 66 & $\begin{array}{l}2 \\
1\end{array}$ & 397 & Tinggi \\
\hline $\mathrm{X} 1.5$ & $\begin{array}{l}\text { Konsumen membeli } \\
\text { shampo merek } \\
\text { Pantene hanya } \\
\text { karena iklan yang } \\
\text { diperankan endorser }\end{array}$ & 1 & 1 & 9 & 63 & $\begin{array}{l}2 \\
6\end{array}$ & 412 & Tinggi \\
\hline X1.6 & $\begin{array}{l}\text { Endorser sering } \\
\text { diberitakan dimedia }\end{array}$ & 1 & 9 & 3 & 62 & $\begin{array}{l}2 \\
5\end{array}$ & 401 & Tinggi \\
\hline X1.7 & $\begin{array}{l}\text { Endorser sering } \\
\text { menjadi bintang } \\
\text { tamu disebuah acara }\end{array}$ & 1 & 1 & 9 & 63 & $\begin{array}{l}2 \\
6\end{array}$ & 412 & Tinggi \\
\hline $\mathrm{X} 1.8$ & $\begin{array}{l}\text { Shampo merek } \\
\text { Pantene memiliki } \\
\text { logo yang mudah } \\
\text { diingat }\end{array}$ & 1 & 1 & 8 & 67 & $\begin{array}{l}2 \\
3\end{array}$ & 410 & Tinggi \\
\hline X1.9 & $\begin{array}{l}\text { Endorser sering } \\
\text { menjadi pemeran } \\
\text { film }\end{array}$ & 1 & 9 & 3 & 63 & $\begin{array}{l}2 \\
4\end{array}$ & 400 & Tinggi \\
\hline $\mathrm{X} 1.10$ & $\begin{array}{l}\text { Shampo merek } \\
\text { Pantene lebih mudah }\end{array}$ & 2 & 9 & 4 & 62 & $\begin{array}{l}2 \\
3 \\
\end{array}$ & 395 & Tinggi \\
\hline
\end{tabular}




\begin{tabular}{|c|c|c|c|c|c|c|}
\hline \multirow[t]{2}{*}{ item } & \multirow[t]{2}{*}{ Keterangan } & $\begin{array}{l}\text { Jawaban } \\
\text { responden }\end{array}$ & indika & & \multirow{2}{*}{$\begin{array}{l}\text { Skor } \\
\text { total }\end{array}$} & \multirow[t]{2}{*}{ Kriteria } \\
\hline & & $\begin{array}{lll}1 & 2 & 3\end{array}$ & 4 & 5 & & \\
\hline & $\begin{array}{l}\text { dikenali karena } \\
\text { endorser }\end{array}$ & & & & & \\
\hline TOTAL & Rata-rata & & & & $\begin{array}{l}2822 \\
403,14\end{array}$ & Tinggi \\
\hline
\end{tabular}

Berdasarkan hasil perhitungan rentang skala yang disajikan pada tabel 2 diatas dapat dapat dijelaskan sebagai berikut:

1. Endorser sangat populer dalam iklan produk shampo merek Pantene.

Berdasarkan tabel 2 diatas dapat diketahui bahwa kepopuleran endorser dalam iklan produk shampo merek Pantene tinggi dengan skor 394. Hal ini terbukti dari 100 responden sebesar 1 responden menjawab sangat tidak setuju, 10 responden menjawab tidak setuju, 4 responden menjawab normal, 64 responden menjawab setuju dan 21 responden menjawab sangat setuju tentang kepopuleran endorser dalam iklan produk shampo merek Pantene.

2. Endorser memiliki rambut yang bagus dibandingkan dengan bintang iklan shampo lain

Berdasarkan tabel 2 diatas dapat diketahui bahwa endorser memiliki rambut yang bagus dibandingkan dengan bintang iklan shampo lain mendapatkan skor atau nilai 412 yang berarti masuk dalam kriteria penilaian tinggi. Hal ini terbukti dari 100 responden sebesar 1 responden menjawab sangat tidak setuju, 1 responden menjawab tidak setuju, 8 responden menjawab normal, 65 responden menjawab setuju dan 25 responden menjawab sangat setuju bahwa endorser memiliki rambut yang bagus dibandingkan dengan bintang iklan shampo lain.

3. Endorser memiliki gaya rambut yang sesuai dengan produk yang diiklankan

Berdasarkan tabel 2 diatas dapat diketahui bahwa endorser memiliki gaya rambut yang sesuai dengan produk yang diiklankan mendapatkan skor atau nilai 398 yang berarti masuk dalam kriteria penilaian tinggi. Hal ini terbukti dari 100 responden sebesar 1 responden menjawab sangat tidak setuju, 9 responden menjawab tidak setuju, 4 responden menjawab normal, 63 responden menjawab setuju dan 23 responden menjawab sangat setuju bahwa endorser memiliki gaya rambut yang sesuai dengan produk yang diiklankan.

4. Konsumen shampo merek Pantene memiliki tingkat kekaguman yang tinggi terhadap endorser

Berdasarkan tabel 2 diatas dapat diketahui bahwa konsumen shampo merek Pantene memiliki tingkat kekaguman yang tinggi terhadap endorser mendapatkan skor atau nilai 397 yang berarti masuk dalam kriteria penilaian tinggi. Hal ini terbukti dari 100 responden sebesar 1 responden menjawab sangat tidak setuju, 9 responden menjawab tidak setuju, 3 responden menjawab normal, 66 responden menjawab setuju dan 21 responden menjawab sangat setuju bahwa konsumen shampo merek Pantene memiliki tingkat kekaguman yang tinggi terhadap endorser.

5. Konsumen membeli shampo merek Pantene hanya karena iklan yang diperankan endorser

Berdasarkan tabel 2 diatas dapat diketahui bahwa konsumen membeli shampo merek Pantene hanya karena iklan yang diperankan endorser mendapatkan skor atau nilai 412 yang berarti masuk dalam kriteria penilaian tinggi. Hal ini terbukti dari 100 responden sebesar 1 responden menjawab sangat tidak setuju, 1 responden menjawab tidak setuju, 9 responden menjawab normal, 63 responden menjawab setuju dan 26 responden menjawab sangat setuju bahwa Konsumen membeli shampo merek Pantene hanya karena iklan yang diperankan endorser.

6. Endorser sering diberitakan di media

Berdasarkan tabel 2 diatas dapat diketahui bahwa shampo merek Pantene memiliki kemasan yang menarik mendapatkan skor atau nilai 401 yang berarti masuk dalam kriteria penilaian tinggi. Hal ini terbukti dari 100 responden sebesar 1 responden menjawab sangat tidak setuju, 9 responden menjawab tidak setuju, 3 responden menjawab normal, 62 responden menjawab setuju dan 25 responden menjawab sangat setuju bahwa shampo merek Pantene memiliki kemasan yang menarik.

7. Endorser sering menjadi bintang tamu disebuah acara

Berdasarkan tabel 2 diatas dapat diketahui bahwa shampo merek Pantene memiliki kualitas produk yang khas mendapatkan skor atau nilai 412 yang berarti masuk dalam kriteria penilaian tinggi. Hal ini terbukti dari 100 responden sebesar 1 responden menjawab sangat tidak setuju, 1 responden menjawab tidak setuju, 9 responden menjawab normal, 63 responden menjawab setuju dan 26 responden menjawab sangat setuju bahwa Shampo Merek Pantene memiliki kualitas produk yang khas.

8. Shampo merek Pantene memiliki logo yang mudah diingat 
Berdasarkan tabel 2 diatas dapat diketahui bahwa shampo merek Pantene memiliki logo yang mudah diingat mendapatkan skor atau nilai 410 yang berarti masuk dalam kriteria penilaian tinggi. Hal ini terbukti dari 100 responden sebesar 1 responden menjawab sangat tidak setuju, 1 responden menjawab tidak setuju, 8 responden menjawab normal, 67 responden menjawab setuju dan 23 responden menjawab sangat setuju bahwa shampo merek Pantene memiliki logo yang mudah diingat.

9. Endorser sering menjadi pemeran disebuah film

Berdasarkan tabel 2 diatas dapat diketahui bahwa shampo merek Pantene sudah terkenal sejak dahulu mendapatkan skor atau nilai 400 yang berarti masuk dalam kriteria penilaian tinggi. Hal ini terbukti dari 100 responden sebesar 1 responden menjawab sangat tidak setuju, 9 responden menjawab tidak setuju, 3 responden menjawab normal, 63 responden menjawab setuju dan 24 responden menjawab sangat setuju bahwa shampo merek Pantene sudah terkenal sejak dahulu.

10. Shampo merek Pantene lebih mudah dikenali karena endorsernya

Berdasarkan tabel 2 diatas dapat diketahui bahwa shampo merek Pantene lebih mudah dikenali karena endorsernya mendapatkan skor atau nilai 395 yang berarti masuk dalam kriteria penilaian tinggi. Hal ini terbukti dari 100 responden sebesar 2 responden menjawab sangat tidak setuju, 9 responden menjawab tidak setuju, 4 responden menjawab normal, 62 responden menjawab setuju dan 23 responden menjawab sangat setuju bahwa shampo merek Pantene lebih mudah dikenali karena endorsernya.

Berdasarkan tabel di atas rata-rata skor indikator sebesar 403,10 termasuk dengan kriteria tinggi artinya persepsi konsumen tinggi terhadap visibility endoser produk shampo merek Pantene.

Tabel 3. Variabel Credibility

\begin{tabular}{|c|c|c|c|c|c|c|c|c|}
\hline \multirow{2}{*}{ item } & \multirow{2}{*}{ Keterangan } & \multicolumn{5}{|c|}{ Jawaban indikator responden } & \multirow{2}{*}{$\begin{array}{l}\text { Skor } \\
\text { total }\end{array}$} & \multirow{2}{*}{ Kriteria } \\
\hline & & 1 & 2 & 3 & 4 & 5 & & \\
\hline $\mathrm{X} 2.1$ & $\begin{array}{l}\text { Pengetahuan yang luas dan } \\
\text { spesifik endorser dalam iklan } \\
\text { produk shampo merek Pantene }\end{array}$ & 1 & 9 & 2 & 65 & 23 & 400 & Tinggi \\
\hline $\mathrm{X} 2.2$ & $\begin{array}{l}\text { Endorser dapat dipercaya dalam } \\
\text { menyampaikan produk shampo } \\
\text { Pantene }\end{array}$ & 1 & 1 & 8 & 66 & 24 & 411 & Tinggi \\
\hline $\mathrm{X} 2.3$ & $\begin{array}{l}\text { Memiliki relevansi antara } \\
\text { produk yang diiklankan dengan } \\
\text { gaya rambut yang dimiliki } \\
\text { endorser }\end{array}$ & 1 & 9 & 3 & 59 & 28 & 404 & Tinggi \\
\hline $\mathrm{X} 2.4$ & $\begin{array}{l}\text { Karakteristik pribadi dari } \\
\text { endorser sangat mendukung } \\
\text { iklan produk shampo Pantene }\end{array}$ & 1 & 9 & 3 & 61 & 26 & 402 & Tinggi \\
\hline $\mathrm{X} 2.5$ & $\begin{array}{l}\text { Produk shampo Pantene } \\
\text { memiliki nilai jual yang tinggi } \\
\text { karena diiklankan oleh endorser }\end{array}$ & 1 & 1 & 8 & 68 & 22 & 409 & Tinggi \\
\hline $\mathrm{X} 2.6$ & $\begin{array}{l}\text { Konsumen loyal memakai } \\
\text { produk shampo Pantene karena } \\
\text { endorser }\end{array}$ & 1 & 9 & 3 & 62 & 25 & 401 & Tinggi \\
\hline $\mathrm{X} 2.7$ & $\begin{array}{l}\text { Produk shampo Pantene tidak } \\
\text { ada nilainya jika iklan tidak } \\
\text { diperankan oleh endorser }\end{array}$ & 2 & 8 & 4 & 65 & 21 & 395 & Tinggi \\
\hline TOTAI & Rata-rata & & & & & & $\begin{array}{l}2822 \\
403,14\end{array}$ & Tinggi \\
\hline
\end{tabular}

Berdasarkan hasil perhitungan rentang skala yang disajikan pada tabel 3 diatas dapat dapat dijelaskan sebagai berikut:

1. Pengetahuan yang luas dan spesifik endorser dalam iklan produk shampo merek Pantene

Berdasarkan tabel 3 diatas dapat diketahui bahwa pengetahuan yang luas dan spesifik endorser dalam iklan produk shampo merek Pantene mendapatkan skor atau nilai 400 yang berarti masuk dalam kriteria penilaian tinggi. Hal ini terbukti dari 100 responden sebesar 1 responden menjawab sangat tidak setuju, 9 responden menjawab tidak setuju, 2 responden menjawab normal, 65 responden menjawab setuju dan 23 responden menjawab sangat setuju tentang pengetahuan yang luas dan spesifik endorser dalam iklan produk shampo merek Pantene.

2. Endorser dapat dipercaya dalam menyampaikan produk shampo Pantene 
Berdasarkan tabel 3 diatas dapat diketahui bahwa endorser dapat dipercaya dalam menyampaikan produk shampo Pantene mendapatkan skor atau nilai 411 yang berarti masuk dalam kriteria penilaian tinggi. Hal ini terbukti dari 100 responden sebesar 1 responden menjawab sangat tidak setuju, 1 responden menjawab tidak setuju, 8 responden menjawab normal, 66 responden menjawab setuju dan 24 responden menjawab sangat setuju bahwa endorser dapat dipercaya dalam menyampaikan produk shampo Pantene.

3. Memiliki relevansi antara produk yang diiklankan dengan gaya rambut yang dimiliki endorser

Berdasarkan tabel 3 diatas dapat diketahui bahwa memiliki relevansi antara produk yang diiklankan dengan gaya rambut yang dimiliki endorser mendapatkan skor atau nilai 404 yang berarti masuk dalam kriteria penilaian tinggi. Hal ini terbukti dari 100 responden sebesar 1 responden menjawab sangat tidak setuju, 9 responden menjawab tidak setuju, 3 responden menjawab normal, 59 responden menjawab setuju dan 28 responden menjawab sangat setuju bahwa memiliki relevansi antara produk yang diiklankan dengan gaya rambut yang dimiliki endorser

4. Karakteristik pribadi dari endorser sangat mendukung iklan produk shampo Pantene

Berdasarkan tabel 3 diatas dapat diketahui bahwa Karakteristik pribadi dari endorser sangat mendukung iklan produk shampo Pantene mendapatkan skor atau nilai 402 yang berarti masuk dalam kriteria penilaian tinggi. Hal ini terbukti dari 100 responden sebesar 1 responden menjawab sangat tidak setuju, 9 responden menjawab tidak setuju, 3 responden menjawab normal, 61 responden menjawab setuju dan 26 responden menjawab sangat setuju bahwa Karakteristik pribadi dari endorser sangat mendukung iklan produk shampo Pantene.

5. Produk shampo Pantene memiliki nilai jual yang tinggi karena diiklankan oleh endorser

Berdasarkan tabel 3 diatas dapat diketahui bahwa produk shampo Pantene memiliki nilai jual yang tinggi karena diiklankan oleh endorser mendapatkan skor atau nilai 409 yang berarti masuk dalam kriteria penilaian tinggi. Hal ini terbukti dari 100 responden sebesar 1 responden menjawab sangat tidak setuju, 1 responden menjawab tidak setuju, 8 responden menjawab normal, 68 responden menjawab setuju dan 22 responden menjawab sangat setuju bahwa produk shampo Pantene memiliki nilai jual yang tinggi karena diiklankan oleh endorser.

6. Konsumen loyal memakai produk shampo Pantene karena endorser

Berdasarkan tabel 3 diatas dapat diketahui bahwa konsumen loyal memakai produk shampo Pantene karena endorser mendapatkan skor atau nilai 401 yang berarti masuk dalam kriteria penilaian tinggi. Hal ini terbukti dari 100 responden sebesar 1 responden menjawab sangat tidak setuju, 9 responden menjawab tidak setuju, 3 responden menjawab normal, 62 responden menjawab setuju dan 25 responden menjawab sangat setuju bahwa Konsumen loyal memakai produk shampo Pantene karena endorser.

7. Produk shampo Pantene tidak ada nilainya jika iklan tidak diperankan oleh endorser

Berdasarkan tabel 3 diatas dapat diketahui bahwa produk shampo Pantene tidak ada nilainya jika iklan tidak diperankan oleh endorser mendapatkan skor atau nilai 395 yang berarti masuk dalam kriteria penilaian tinggi. Hal ini terbukti dari 100 responden sebesar 2 responden menjawab sangat tidak setuju, 8 responden menjawab tidak setuju, 4 responden menjawab normal, 65 responden menjawab setuju dan 21 responden menjawab sangat setuju bahwa produk shampo Pantene tidak ada nilainya jika iklan tidak diperankan oleh endorser.

Berdasarkan tabel di atas rata-rata skor indikator sebesar 403,14 termasuk dengan kriteria tinggi artinya persepsi konsumen tinggi terhadap credibility endoser produk shampo merek Pantene.

Tabel 4. Variabel Attraction

\begin{tabular}{|c|c|c|c|c|c|c|c|c|}
\hline \multirow[t]{2}{*}{ item } & \multirow[t]{2}{*}{ Keterangan } & \multicolumn{3}{|c|}{$\begin{array}{l}\text { Jawaban } \\
\text { responden }\end{array}$} & \multicolumn{2}{|c|}{ indikator } & \multirow{2}{*}{$\begin{array}{l}\text { Skor } \\
\text { total }\end{array}$} & \multirow[t]{2}{*}{ Kriteria } \\
\hline & & 1 & 2 & 3 & 4 & 5 & & \\
\hline $\mathrm{X} 3.1$ & $\begin{array}{lr}\text { Endorser sangat } & \text { menarik } \\
\text { dalam iklan } & \text { produk } \\
\text { shampo Pantene } & \end{array}$ & 1 & 10 & 3 & 64 & 22 & 396 & Tinggi \\
\hline X3.2 & $\begin{array}{l}\text { Tampilan yang sempurna } \\
\text { endorser dalam iklan } \\
\text { produk shampo Pantene }\end{array}$ & 1 & 1 & 8 & 65 & 25 & 412 & Tinggi \\
\hline X3.3 & $\begin{array}{lr}\text { Gaya iklan } & \text { yang } \\
\text { ditampilkan } & \text { endorser } \\
\text { sesuai dengan } & \text { karakter } \\
\text { konsumen } & \text { shampo } \\
\text { Pantene } & \end{array}$ & 1 & 9 & 4 & 61 & 25 & 400 & Tinggi \\
\hline
\end{tabular}




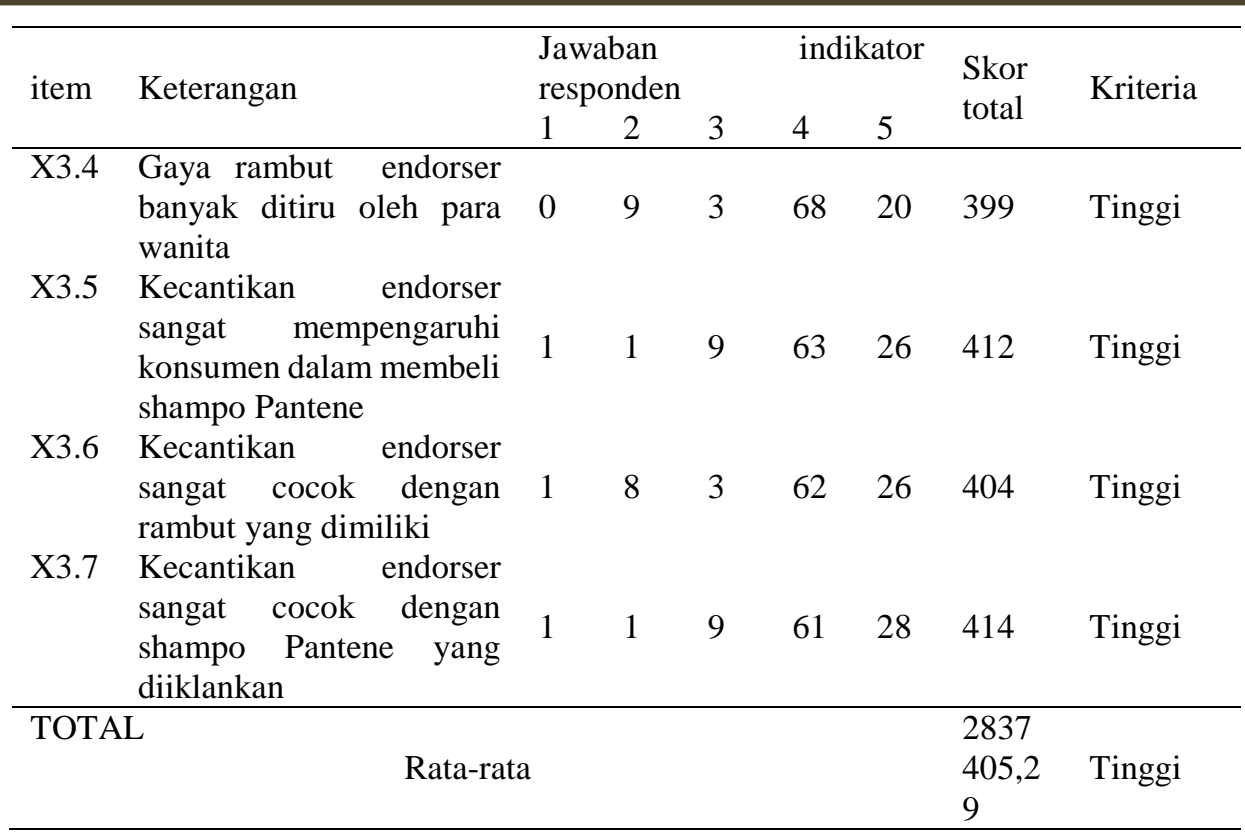

Berdasarkan hasil perhitungan rentang skala yang disajikan pada tabel 4 diatas dapat dapat dijelaskan sebagai berikut:

1. Endorser sangat menarik dalam iklan produk shampo Pantene

Berdasarkan tabel 4 diatas dapat diketahui bahwa endorser sangat menarik dalam iklan produk shampo Pantene mendapatkan skor atau nilai 396 yang berarti masuk dalam kriteria penilaian tinggi. Hal ini terbukti dari 100 responden sebesar 1 responden menjawab sangat tidak setuju, 10 responden menjawab tidak setuju, 3 responden menjawab normal, 64 responden menjawab setuju dan 22 responden menjawab sangat setuju tentang endorser sangat menarik dalam iklan produk shampo Pantene.

2. Tampilan yang sempurna endorser dalam iklan produk shampo Pantene

Berdasarkan tabel 4 diatas dapat diketahui bahwa tampilan yang sempurna endorser dalam iklan produk shampo Pantene mendapatkan skor atau nilai 412 yang berarti masuk dalam kriteria penilaian tinggi. Hal ini terbukti dari 100 responden sebesar 1 responden menjawab sangat tidak setuju, 1 responden menjawab tidak setuju, 8 responden menjawab normal, 65 responden menjawab setuju dan 25 responden menjawab sangat setuju bahwa Tampilan yang sempurna endorser dalam iklan produk shampo Pantene.

3. Gaya iklan yang ditampilkan endorser sesuai dengan karakter konsumen shampo Pantene

Berdasarkan tabel 4 diatas dapat diketahui bahwa gaya iklan yang ditampilkan endorser sesuai dengan karakter konsumen shampo Pantene mendapatkan skor atau nilai 400 yang berarti masuk dalam kriteria penilaian tinggi. Hal ini terbukti dari 100 responden sebesar 1 responden menjawab sangat tidak setuju, 9 responden menjawab tidak setuju, 4 responden menjawab normal, 61 responden menjawab setuju dan 25 responden menjawab sangat setuju bahwa gaya iklan yang ditampilkan endorser sesuai dengan karakter konsumen shampo Pantene.

4. Gaya rambut endorser banyak ditiru oleh para wanita

Berdasarkan tabel 4 diatas dapat diketahui bahwa gaya rambut endorser banyak ditiru oleh para wanita mendapatkan skor atau nilai 399 yang berarti masuk dalam kriteria penilaian tinggi. Hal ini terbukti dari 100 responden sebesar 9 responden menjawab tidak setuju, 3 responden menjawab normal, 68 responden menjawab setuju dan 20 responden menjawab sangat setuju bahwa gaya rambut endorser banyak ditiru oleh para wanita.

5. Kecantikan endorser sangat mempengaruhi konsumen dalam membeli shampo Pantene

Berdasarkan tabel 4 diatas dapat diketahui bahwa kecantikan endorser sangat mempengaruhi konsumen dalam membeli shampo Pantene mendapatkan skor atau nilai 412 yang berarti masuk dalam kriteria penilaian tinggi. Hal ini terbukti dari 100 responden sebesar 1 responden menjawab sangat tidak setuju, 1 responden menjawab tidak setuju, 9 responden menjawab normal, 63 responden menjawab setuju dan 26 responden menjawab sangat setuju bahwa kecantikan endorser sangat mempengaruhi konsumen dalam membeli shampo Pantene.

6. Kecantikan endorser sangat cocok dengan rambut yang dimiliki

Berdasarkan tabel 4 diatas dapat diketahui bahwa kecantikan endorser sangat cocok dengan rambut yang dimiliki mendapatkan skor atau nilai 404 yang berarti masuk dalam kriteria penilaian tinggi. 
Hal ini terbukti dari 100 responden sebesar 1 responden menjawab sangat tidak setuju, 8 responden menjawab tidak setuju, 3 responden menjawab normal, 62 responden menjawab setuju dan 26 responden menjawab sangat setuju bahwa kecantikan endorser sangat cocok dengan rambut yang dimiliki.

7. Kecantikan endorser sangat cocok dengan shampo Pantene yang diiklankan

Berdasarkan tabel 4 diatas dapat diketahui bahwa kecantikan endorser sangat cocok dengan shampo Pantene yang diiklankan mendapatkan skor atau nilai 414 yang berarti masuk dalam kriteria penilaian tinggi. Hal ini terbukti dari 100 responden sebesar 1 responden menjawab sangat tidak setuju, 1 responden menjawab tidak setuju, 9 responden menjawab normal, 61 responden menjawab setuju dan 28 responden menjawab sangat setuju bahwa kecantikan endorser sangat cocok dengan shampo Pantene yang diiklankan.

Berdasarkan tabel di atas rata-rata skor indikator sebesar 405,29 termasuk dengan kriteria tinggi artinya persepsi konsumen tinggi terhadap attraction endoser produk shampo Pantene.

Tabel 5. Variabel Power

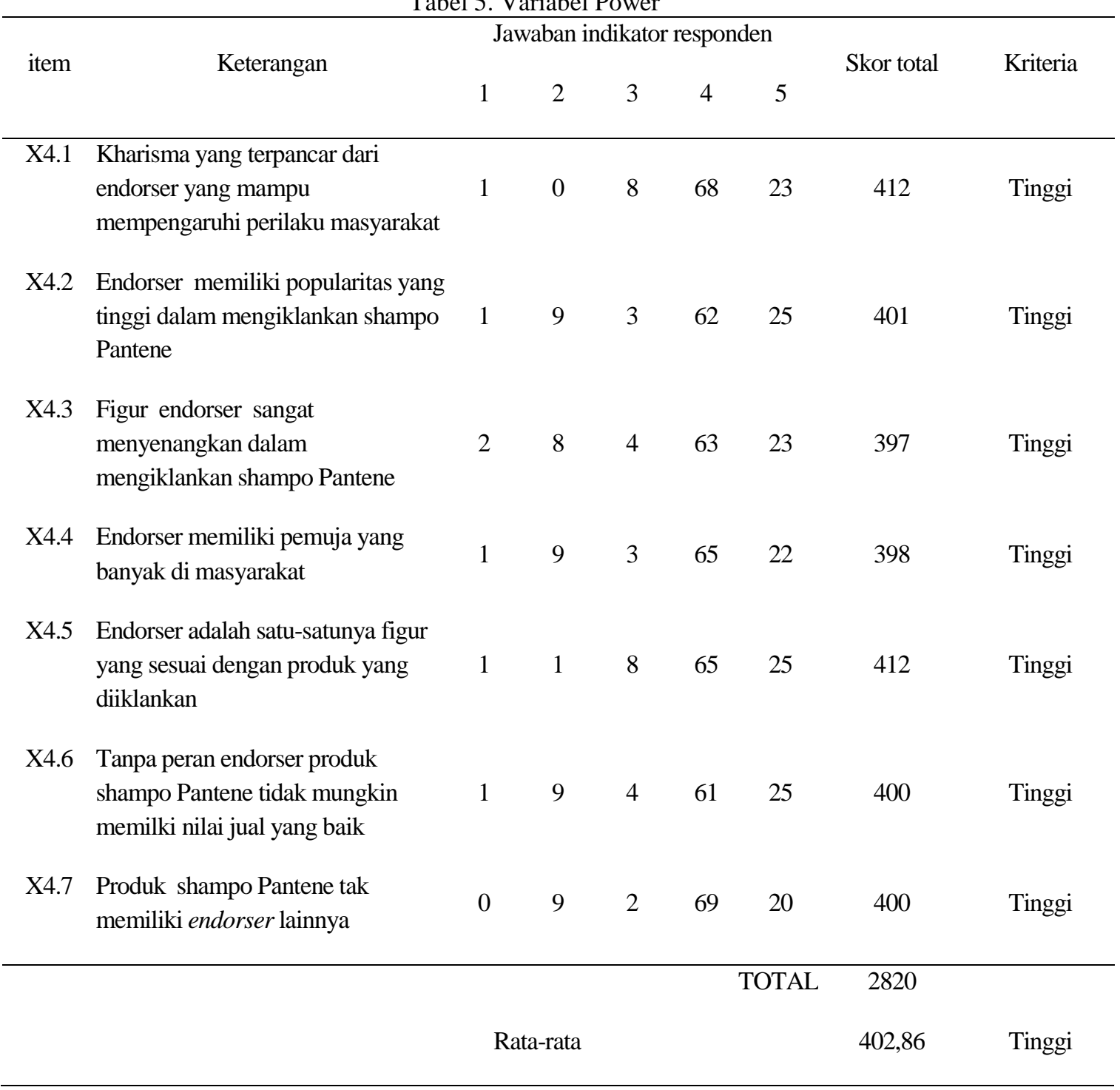

Berdasarkan hasil perhitungan rentang skala yang disajikan pada tabel 5 diatas dapat dapat dijelaskan sebagai berikut:

1. Kharisma yang terpancar dari endorser yang mampu mempengaruhi perilaku masyarakat

Berdasarkan tabel 5 diatas dapat diketahui bahwa kharisma yang terpancar dari endorser yang mampu mempengaruhi perilaku masyarakat mendapatkan skor atau nilai 412 yang berarti masuk dalam kriteria penilaian tinggi. Hal ini terbukti dari 100 responden sebesar 1 responden menjawab sangat tidak 
setuju, 8 responden menjawab normal, 68 responden menjawab setuju dan 23 responden menjawab sangat setuju tentang kharisma yang terpancar dari endorser yang mampu mempengaruhi perilaku masyarakat.

2. Endorser memiliki popularitas yang tinggi dalam mengiklankan shampo Pantene

Berdasarkan tabel 5 diatas dapat diketahui bahwa endorser memiliki popularitas yang tinggi dalam mengiklankan shampo Pantene mendapatkan skor atau nilai 401 yang berarti masuk dalam kriteria penilaian tinggi. Hal ini terbukti dari 100 responden sebesar 1 responden menjawab sangat tidak setuju, 9 responden menjawab tidak setuju, 3 responden menjawab normal, 62 responden menjawab setuju dan 22 responden menjawab sangat setuju bahwa endorser memiliki popularitas yang tinggi dalam mengiklankan shampo Pantene.

3. Figur endorser sangat menyenangkan dalam mengiklankan shampo Pantene

Berdasarkan tabel 5 diatas dapat diketahui bahwa figur endorser sangat menyenangkan dalam mengiklankan shampo Pantene mendapatkan skor atau nilai 397 yang berarti masuk dalam kriteria penilaian tinggi. Hal ini terbukti dari 100 responden sebesar 2 responden menjawab sangat tidak setuju, 8 responden menjawab tidak setuju, 4 responden menjawab normal, 63 responden menjawab setuju dan 23 responden menjawab sangat setuju bahwa figur endorser sangat menyenangkan dalam mengiklankan shampo Pantene.

4. Endorser memiliki pemuja yang banyak di masyarakat

Berdasarkan tabel 5 diatas dapat diketahui bahwa endorser memiliki pemuja yang banyak di masyarakat mendapatkan skor atau nilai 398 yang berarti masuk dalam kriteria penilaian tinggi. Hal ini terbukti dari 100 responden sebesar 1 responden menjawab tidak setuju, 9 responden menjawab tidak setuju, 3 responden menjawab normal, 65 responden menjawab setuju dan 25 responden menjawab sangat setuju bahwa endorser memiliki pemuja yang banyak di masyarakat.

5. Endorser adalah satu-satunya figur yang sesuai dengan produk yang diiklankan

Berdasarkan tabel 5 diatas dapat diketahui bahwa endorser adalah satu-satunya figur yang sesuai dengan produk yang diiklankan mendapatkan skor atau nilai 412 yang berarti masuk dalam kriteria penilaian tinggi. Hal ini terbukti dari 100 responden sebesar 1 responden menjawab sangat tidak setuju, 1 responden menjawab tidak setuju, 8 responden menjawab normal, 65 responden menjawab setuju dan 25 responden menjawab sangat setuju bahwa endorser adalah satu-satunya figur yang sesuai dengan produk yang diiklankan.

6. Tanpa peran endorser produk shampo Pantene tidak mungkin memilki nilai jual yang baik

Berdasarkan tabel 5 diatas dapat diketahui bahwa tanpa peran endorser produk shampo Pantene tidak mungkin memilki nilai jual yang baik mendapatkan skor atau nilai 400 yang berarti masuk dalam kriteria penilaian tinggi. Hal ini terbukti dari 100 responden sebesar 1 responden menjawab sangat tidak setuju, 9 responden menjawab tidak setuju, 4 responden menjawab normal, 61 responden menjawab setuju dan 25 responden menjawab sangat setuju bahwa tanpa peran endorser produk shampo Pantene tidak mungkin memilki nilai jual yang baik.

7. Produk shampo Pantene tak memiliki endorser lainnya

Berdasarkan tabel 5 diatas dapat diketahui bahwa produk shampo Pantene tak memiliki endorser lainnya yang diiklankan mendapatkan skor atau nilai 400 yang berarti masuk dalam kriteria penilaian tinggi. Hal ini terbukti dari 100 responden sebesar 9 responden menjawab tidak setuju, 2 responden menjawab normal, 69 responden menjawab setuju dan 20 responden menjawab sangat setuju bahwa produk shampo Pantene tak memiliki endorser lainnya.

Berdasarkan tabel di atas rata-rata skor indikator sebesar 402,86 termasuk dengan kriteria tinggi artinya persepsi konsumen tinggi terhadap power endoser produk shampo merek Pantene.

Tabel 6. Rata-rata rentang skala

\begin{tabular}{lll}
\hline No & Variabel & Nilai Rentang Skala \\
\hline 1 & Visibility & 403.1 \\
2 & Credebility & 403.14 \\
3 & Attraction & 405.29 \\
4 & Power & 402.86 \\
\hline Rata-rata & 403.60 \\
\hline
\end{tabular}

Berdasarkan tabel 6. di atas rata-rata skor persepsi konsumen pada endorser sebesar 403,60 yang berarti berada pada rentang skala tinggi. 


\section{KESIMPULAN DAN SARAN}

Berdasarkan hasil penelitian dan pembahasannya, maka dapat ditarik kesimpulan bahwa:

1. Persepsi konsumen tinggi pada endorser produk shampo merek Pantene.

2. Variabel attraction adalah yang paling tertinggi/terbaik mendapatkan respon positif dari persepsi konsumen diantara variable visibility, credibility, attraction dan power yang digunakan sebagai endorser suatu produk.

Bagi produsen hendaknya dapat mempertahankan komunikasi pemasaran yang dilakukan dikarenakan tingkat kepopuleran, kekaguman, keseringan muncul dimedia, expertise dalam memasarkan produk, dapat dipercaya, relevansi produk yang disampaikan dengan rambut yang dimiliki, menarik kepribadian, cantik, kekuatan untuk meningkatkan image, kekuatan untuk menjadi inspirasi, kekuatan untuk mengingatkan produk tinggi oleh konsumen, sehingga kredibilitas perusahaan bisa di terima dengan baik oleh para konsumen.

Bagi pihak perusahaan dapat meningkatkan selebriti yang mempunyai daya tarik fisik/penampilan yang menarik, berkualitas baik dari segi kepribadian maupun kecantikan yang dimiliki endorser. Agar hasil penelitian ini lebih sempurna maka hendaknya bagi peneiliti berikutnya bisa menambahkan indikator-indikator, jumlah responden yang digunakan atau menggunakan alat analisis yang berbeda.

\section{REFERENSI}

Arikunto, Suharsimi. 1991. Prosedur Penelitian; Suatu Pendekatan Praktek Edisi. Revisi. PT Rineka Cipta. Jakarta. Ardianto, dan Komala, Lukiah. 2004. Komunikasi Massa : Suatu Pengantar. Simbiosa.

Baksin, Askurifai. 2006. Jurnalistik Televisi: Teori dan Praktik. Bandung: Simbiosa.

Bilson Simamora, 2002, Panduan Riset Perilaku Konsumen, Surabaya: Pustaka.

Buchory, Achmad Herry \& Saladin Djaslim. 2008.Manajemen Pemasaran:Edisi Pertama.Bandung:Linda Karya

Belch, George E, dan Belch, Michael A. 2004. Advertising and Promotion, An Integrated Marketing Communications Perspective, sixth edition.

Hapsari. 2008. Analisis Perbandingan Penggunaan Celebrity. Endorser Dan Typical-Person Endorser Iklan Televisi Jakarta. Penerbit Salemba. Empat.]

Hardiman. IMA, 400 Istilah PR Media \& Periklanan, Gagas Ulung, Jakarta]

Kotler, P. \& Keller, K.L. 2007. Manajemen Pemasaran, Ed12. Jilid 2. Penerbit PT Indeks : Jakarta.]

Malhotra, N.K. 2004. Marketing Research: An Applied Orientation. 4 th. Edition.]

O’Mahony, Sheila and Meenaghan, Tony. 1998. The Impact of Celebrity Endorsements on Customers

Royan, Frans M. 2004. Marketing Selebrities. Jakarta: PT Elex Media Komputindo.

Peter, J. Paul, 2000, Perilaku Konsumen dan Strategi Pemasaran, Jakarta: Ardadizya

Schiffman, Leon, \& Kanuk, Leslie Lazar. 2008. Consumer Behaviour 7 th. Edition. (Perilaku Konsumen). Jakarta: PT. Indeks.

Shimp, Terence A. 2000. Periklanan Promosi. Jakarta: Penerbit Erlangga.

Sugiyono, 2002. Metode Penelitian Bisnis. Cetakan Kedua. Bandung. CV Alfa Beta

Suryani, Tatik, 2008. Perilaku Konsumen: Implikasi Pada Strategi Pemasaran, Yogyakarta: Graha Ilmu

Suyanto. 2004, Aplikasi Desain Grafis untuk Periklanan. Andi,. Yogyakarta

Zikmund. 2004, Metode Penelitian. Jakarta 